\title{
Erythrocyte Lipids in Infants with Low Birth Weights
}

\author{
Robert C. Neerhout ${ }^{[38]}$ \\ Division of Hematology, Department of Pediatrics and The Gwynne Hazen Cherry Memorial Laboratory, University of Galifornia \\ School of Medicine, Los Angeles, California, USA
}

\begin{abstract}
Extract
The lipid composition of erythrocytes, obtained from the cord blood of prematurely born, low birth weight infants, was compared with that obtained from term infants. Infants weighing less than $1,200 \mathrm{~g}$ at birth had increased total lipids, lipid phosphorus $(\mathrm{P})$, and cholesterol per cell (total lipid $=7.60 \times 10^{-10} \mathrm{mg}$; lipid $\mathrm{P}=1.80 \times 10^{-11}$ $\mathrm{mg}$; cholesterol $=2.10 \times 10^{-10} \mathrm{mg}$ ) when compared with controls (total lipid $=$ $6.45 \times 10^{-10} \mathrm{mg} ;$ lipid $\mathrm{P}=1.54 \times 10^{-11} \mathrm{mg} ;$ cholesterol $\left.=1.79 \times 10^{-10} \mathrm{mg}\right)$. The lipid content per $100 \mathrm{ml}$ packed cells and the percentage of total lipid as phospholipid and cholesterol did not differ significantly over the range of birth weights studied. Phospholipid fractionation showed a higher percentage of phosphatidyl choline in infants under $1,200 \mathrm{~g}$ birth weight $(30.0 \%$ of total lipid P) than that noted in term infants $(27.7 \%$ of total lipid P). The higher levels of combined phosphatidyl serine and phosphatidyl inositol noted in term infant erythrocytes (compared with normal adult cells) were observed in the low birth weight infants. Fatty acids esterified to phospholipids showed an increasing percentage of oleic acid with decreasing birth weight (infants of less than $1,200 \mathrm{~g}$ had $16.0 \%$ total fatty acid; infants of more than $2,500 \mathrm{~g}$ had $11.9 \%$ total fatty acid).
\end{abstract}

\section{Speculation}

These studies suggest that the earliest embryonic erythrocytes have the greatest membrane lipid content although the overall membrane lipid distribution does not vary greatly during fetal life.

\section{Introduction}

Previous studies have shown that the lipid composition of erythrocytes from cord blood of full term infants differs in several respects from that of adult erythrocytes $[7,16]$. There is an increase in total lipid, lipid phosphorus, and cholesterol in the cord blood samples. Phospholipid distribution in cord blood samples reveals generally higher levels of sphingomyelin and lower levels of phosphatidyl choline than are found in adult erythrocytes [16]. Fatty acids esterified to phospholipid reveal higher percentages of palmitic acid, stearic acid, arachidonic acid, and com- bined 22-24 carbon fatty acids associated with decreased percentages of oleic acid and linoleic acid when compared with adult erythrocyte values [16]. Similar studies on lipid values of erythrocytes from prematurely born infants have not been reported.

In comparison with the findings in adults, the levels of total lipid, phospholipid, and cholesterol in plasma are relatively low in the cord blood of term infants $[7,29,30]$. Owing to the lack of significant de novo lipid synthesis [12], the erythrocyte is dependent on its plasma environment for lipid homeostasis either by a mechanism of direct exchange or by conversion of 
plasma monoacyl phospholipid to cellular phospholipid through acylation $[3,13,21,23]$. Despite this dependence on lipid in plasma, the erythrocyte of the term fetus maintains a higher level of lipid while circulating in a relatively low lipid environment. The present study was undertaken to characterize the lipid composition of erythrocytes from the cord blood of prematurely born infants of various birth weights.

\section{Materials and Methods}

Cord blood samples were collected from 16 prematurely born infants; birth weights ranged from 200 to $2,100 \mathrm{~g}$. All infants were born alive although several of the smaller ones were unable to sustain spontaneous respiration. Samples from a set of nonidentical twins with separate placentas are included and represent the two smallest infants (200 and $240 \mathrm{~g}$ ). There were 10 males and 6 females in the study group. No infants with maternal-fetal $R h$ incompatibility were utilized. The infants were not evaluated critically for developmental age and were only compared on the basis of birth weight. It was the opinion of the Obstetrical Staff that the infants selected had birth weights appropriate for their recorded gestational age and no obviously small-for-date babies were included. Results obtained from cord blood samples collected from 42 full term infants reported previously [16], but studied concurrently were used for comparison. This control group contained 24 females and 18 males whose birth weights ranged from 2,520 to 4,500 g. All infants were free of obvious pathology and were not maternal-fetal $\mathrm{Rh}$ incompatible [31].

Blood samples, collected in ethylenediaminetetraacetate (EDTA), were centrifuged at $4^{\circ}$ and the plasma and buffy coat were removed. Cells were washed with

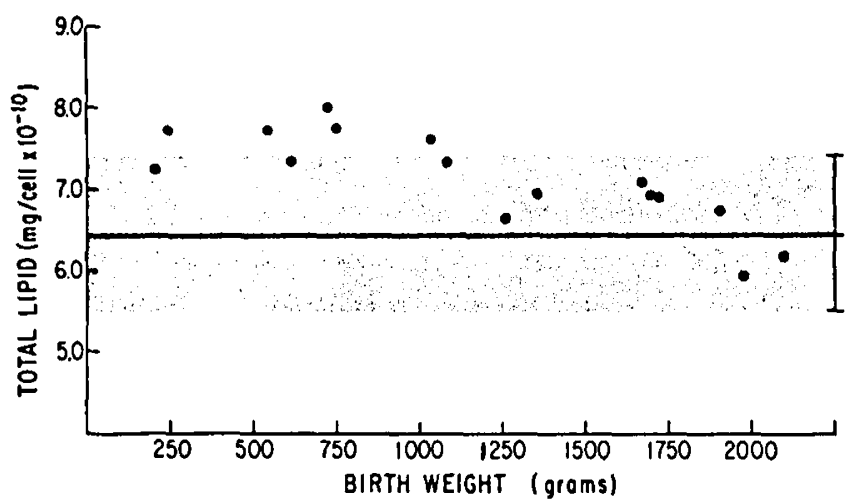

Fig. 1. Total erythrocyte lipid per cell as a function of birth weight. Shaded area denotes the mean \pm sD for infants of greater than $2,500 \mathrm{~g}$ birth weight. saline until the supernatant solution was clear. Red cells were suspended in physiological saline to a hematocrit of $65-75 \%$. An electronic particle counter was used for cell counting [32]. Lipids were extracted twice in chloroform: methanol $(2: 1, \mathrm{v} / \mathrm{v})$ by a modification of the method of Farquhar [8]. All extraction procedures were performed under nitrogen and in the presence of hydroquinone to limit lipid oxidation. The details of this modification are described elsewhere $[14,16]$. Samples of the total lipid extract were taken for the following determinations: (1) total lipid was determined gravimetrically; (2) cholesterol was assayed by the method of Chiamori and Henry [6]; (3) lipid P was assayed by the method of Bartlett [2]; (4) phospholipids were fractionated by thin layer chromatography on silica gel [33] by the method of Skipski et al. [24], and the phosphorus content of individual fractions was determined as described by Parker and Peterson [20]; (5) phospholipids were separated from neutral lipids by column chromatography on silicic acid [27]. Phospholipid fatty acids were methylated [28] and quantitated on a gas chromatograph [34] with hydrogen flame detector utilizing a 6 -ft column packed with diethylene glycol succinate liquid phase on Chromsorb W [35] (oven temperature $180^{\circ}$ ). Fatty acids were identified by comparison with known standards [36] and published retention times [1]. Aldehydes were identified by the method of Farquhar [9]. Statistical comparisons were made by standard $t$ test anlysis.

\section{Results}

Levels of total lipid in cord blood (Fig. 1) are plotted as a function of birth weight and are compared with values for normal term infants. A general trend toward increased total lipid per cell with decreased birth weight was noted. A similar trend was noted in lipid $\mathbf{P}$ and cholesterol per cell. For the purpose of comparison, the study group was divided into two groups on the basis of birth weight (Table I). Eight infants weighed under $1,200 \mathrm{~g}$ and eight weighed between $\mathrm{l}, 200$ and $2,100 \mathrm{~g}$. Infants under $1,200 \mathrm{~g}$ showed sig. nificantly higher values for total lipid, lipid $P$, and cholesterol per cell than normal term infants $(P<$ $0.01)$. These values taken from the group weighing more than $1,200 \mathrm{~g}$ showed no statistically significant variation from term infants in these variables. Comparison based on lipid per $100 \mathrm{ml}$ packed cells rather than lipid per cell revealed similar values in both premature infants and term infants. This similarity is a reflection of increasing mean corpuscular volume (MCV) of the erythrocytes with decreasing birth weight 
Table I. Erythrocyte lipid distribution. Comparison of cord blood erythrocytes from infants of varying birth weights

\begin{tabular}{|c|c|c|c|c|c|c|c|c|}
\hline \multirow{2}{*}{ Birth wt, g } & \multirow[t]{2}{*}{$\begin{array}{l}\text { Total lipid, } \\
\times 10^{-10}\end{array}$} & \multirow{2}{*}{$\begin{array}{c}\begin{array}{c}\text { Lipid phosphorus, } \\
\times 10^{-11}\end{array} \\
\mathrm{mg} / \mathrm{cell}\end{array}$} & \multirow[t]{2}{*}{$\begin{array}{c}\text { Cholesterol, } \\
\times 10^{-10}\end{array}$} & \multirow[t]{2}{*}{ Total lipid } & \multirow{2}{*}{$\begin{array}{l}\text { Lipid phosphorus } \\
\mathrm{mg} / 100 \mathrm{ml} \text { cells }\end{array}$} & \multirow[t]{2}{*}{ Cholesterol } & \multicolumn{2}{|c|}{ Percentage of total lipids } \\
\hline & & & & & & & $\begin{array}{c}\text { Lipid } \\
\text { phosphorus }\end{array}$ & Cholesterol \\
\hline $\begin{array}{l}200-1,200 \\
(N=8)\end{array}$ & $7.60^{1} \pm 0.25^{2}$ & $1.80^{1} \pm 0.05^{2}$ & $2.10^{2} \pm 0.28^{2}$ & $548 \pm 67$ & $13.0 \pm 1.5$ & $152 \pm 31$ & $2.37 \pm 0.11$ & $27.6 \pm 3.8$ \\
\hline $\begin{array}{l}1,200-2,100 \\
(N=8)\end{array}$ & $6.67 \pm 0.39$ & $1.63 \pm 0.07$ & $1.79 \pm 0.18$ & $565 \pm 37$ & $13.8 \pm 0.9$ & $152 \pm 14$ & $2.44 \pm 0.10$ & $26.8 \pm 1.9$ \\
\hline $\begin{array}{l}>2,5003 \\
(N=42)\end{array}$ & $6.45 \pm 0.48$ & $1.54 \pm 0.12$ & $1.79 \pm 0.16$ & $537 \pm 36$ & $12.9 \pm 0.9$ & $148 \pm 12$ & $2.40 \pm 0.17$ & $27.1 \pm 2.3$ \\
\hline
\end{tabular}

${ }^{1}$ Significant at $P<0.01$ when compared with values for infants $>2,500 \mathrm{~g}$ birth weight.

${ }^{2}$ Mean $\pm \mathrm{sD}$.

Ref. 16 .

(MCV infants of less than $1,200 \mathrm{~g}=139 \mu \mathrm{m}^{3} ; \mathrm{MCV}$ infants $1,200-2,100 \mathrm{~g}=118 \mu \mathrm{m}^{3}$; MCV term infants of more than $\left.2,500 \mathrm{~g}=120 \mu \mathrm{m}^{3}\right)$. Thus, the increased lipid per cell in the smaller infants may be accounted for by an increased cell volume and, presumably, an increased cell surface area. The relative amounts of phospholipid and cholesterol per cell, in percentage (Table I), did not differ significantly, suggesting that the lipid distribution per unit of membrane was the same in all groups.

The percentage distribution of individual erythrocyte phospholipids for the 16 premature infants is shown in Table II. Premature infants were grouped by birth weight and compared with normal term infants. The increase in combined phosphatidyl serine and phosphatidyl inositol levels previously noted in erythrocytes from term infants, as compared with adult erythrocytes, was noted in the low birth weight infants. The phospholipid distribution in infants over $1,200 \mathrm{~g}$ birth weight did not differ significantly from that of infants of normal birth weight. Phospholipids in infants under $1,200 \mathrm{~g}$ showed a lower level of sphingomyelin (24.3\% of total lipid P) and a higher level of phosphatidyl choline ( $30.0 \%$ of total lipid $P$ ) when compared with those found in infants of normal birth weight (sphingomyelin 26.0\%, phosphatidyl choline $27.7 \%$ ). Only the difference in phosphatidyl choline was statistically significant $(P<0.01)$. The percentages of phosphatidyl choline and sphingomyelin noted in infants under $1,200 \mathrm{~g}$ birth weight are similar to those previously reported in adult erythrocytes (sphingomyelin $24.1 \%$, phosphatidyl choline $29.5 \%$ [14, 16]).

The fatty acids esterified to phospholipid for low birth weight and normal birth weight infants are shown in Table III. Fatty acids are identified numerically by the carbon chain length and the number of unsaturated double bonds $(18: 2=18$ carbon chain: 2 double bonds; $18 \mathrm{al}=18$ carbon chain aldehyde). Infants with birth weights of less than $1,200 \mathrm{~g}$ showed higher percentages of oleic acid $\left(\mathrm{C}_{18: 1}\right)$ in association with reduced amounts of linoleic acid $\left(\mathrm{C}_{18: 2}\right)$, eicosotrienoic acid $\left(\mathrm{C}_{20: 3}\right)$, and the longer-chain fatty acids $\left(\mathrm{C}_{24: 0}, \mathrm{C}_{22: 0}\right)$. Infants with birth weights between 1,200 and 2,100 g generally had fatty acid values intermediary between the other two study groups. The only statistically significant $(P<0.01)$ variation in fatty acid pattern between the two low birth weight groups was found in the percentage of stearic acid $\left(\mathrm{C}_{18: 0}\right)$.

\section{Discussion}

Previous studies have emphasized several differences in erythrocyte stromal lipid composition between normal adult cells and cord blood cells from normal term infants $[7,16]$. The levels of total lipid, lipid $P$, and cholesterol per cell are greater in cord blood cells than in adu.t cells. The data presented here demonstrate that stromal lipid content per cell found in normal

Table II. Distribution of individual phosphatides in phospholipid fraction ${ }^{1}$

\begin{tabular}{lcccccc}
\hline Birth wt, g & $\begin{array}{c}\text { Lyso- } \\
\text { lecithin }\end{array}$ & $\begin{array}{c}\text { Sphingo- } \\
\text { myelin }\end{array}$ & $\begin{array}{c}\text { Phos- } \\
\text { phatidyl } \\
\text { choline }\end{array}$ & $\begin{array}{c}\text { Phos- } \\
\text { phatidyl } \\
\text { serine }+ \\
\text { phos- } \\
\text { phatidyl } \\
\text { inositol }\end{array}$ & $\begin{array}{c}\text { Phos- } \\
\text { phatidyl } \\
\text { ethanol- } \\
\text { amine }\end{array}$ & $\begin{array}{c}\text { Phos- } \\
\text { phatidic } \\
\text { acid }\end{array}$ \\
\hline $200-1,200$ & & & & & & \\
$(\mathrm{~N}=8)$ & 1.0 & 24.3 & $30.0^{2}$ & 15.6 & 28.5 & 0.7 \\
$1,200-2,100$ & $\pm 0.26^{3}$ & \pm 2.1 & \pm 1.2 & \pm 1.5 & \pm 2.4 & \pm 0.40 \\
$(\mathrm{~N}=8)$ & $0.8^{2}$ & 27.2 & 28.6 & 14.6 & 28.3 & 0.5 \\
$>2,500$ & \pm 0.28 & \pm 2.1 & \pm 2.1 & \pm 1.1 & \pm 1.2 & \pm 0.16 \\
$(\mathrm{~N}=28)$ & 1.0 & 26.0 & 27.7 & 15.2 & 29.1 & 0.9 \\
& \pm 0.10 & \pm 2.8 & \pm 2.1 & \pm 1.6 & \pm 2.9 & \pm 0.49
\end{tabular}

1 Values expressed as percentage of total lipid phosphorus.

2 Significant at $P<0.01$ when compared with values for infants $>2,500 \mathrm{~g}$ birth weight.

- Mean \pm sD. 
Table III. Distribution of fatty acids esterified to phospholipid ${ }^{1}$

\begin{tabular}{|c|c|c|c|c|c|c|}
\hline \multirow{2}{*}{ Fatty acid } & \multicolumn{2}{|c|}{$\begin{array}{l}\text { Birth wt }(N=8) \\
\quad 200-1,200 \mathrm{~g}\end{array}$} & \multicolumn{2}{|c|}{$\begin{array}{c}\text { Birth wt }(N=8) \\
1,200-2,100 \mathrm{~g}\end{array}$} & \multicolumn{2}{|c|}{$\begin{array}{c}\text { Birth w } \mathrm{t}^{2} \\
(N=28)>2,500 \mathrm{~g}\end{array}$} \\
\hline & Mean & $\pm \mathrm{sv}$ & Mean & $\pm \mathrm{SD}$ & Mean & $\pm \mathrm{SD}$ \\
\hline$C_{14: 0^{3}}$ & $0.4^{4}$ & 0.12 & 0.3 & 0.05 & 0.2 & 0.08 \\
\hline $\mathrm{C}_{16 \text { : } 11}$ & $1.6^{4}$ & 0.09 & 1.8 & 0.18 & 2.0 & 0.36 \\
\hline $\mathrm{C}_{16: 0}$ & 20.8 & 1.79 & 21.8 & 2.84 & 21.3 & 2.38 \\
\hline$C_{18: 1}$ & $1.6^{4}$ & 0.33 & $1.8^{4}$ & 0.25 & 1.0 & 0.28 \\
\hline $\mathrm{C}_{17: 0}$ & $0.3^{4}$ & 0.06 & $0.2^{4}$ & 0.05 & 0.1 & 0.05 \\
\hline $\mathrm{C}_{18: \mathrm{n} 1}$ & 3.7 & 0.48 & 3.3 & 0.60 & 3.5 & 0.14 \\
\hline $\mathrm{C}_{18: 0}$ & 15.8 & 0.81 & $17.6^{4}$ & 1.11 & 16.3 & 0.99 \\
\hline $\mathrm{C}_{18: 1}$ & $16.0^{4}$ & 1.71 & $13.6^{6}$ & 1.26 & 11.9 & 1.08 \\
\hline $\mathrm{C}_{18: 2}$ & $2.4^{4}$ & 0.54 & 3.7 & 0.36 & 3.4 & 0.55 \\
\hline $\mathrm{C}_{18: 8}$ & 0.2 & 0.11 & 0.4 & 0.34 & 0.3 & 0.10 \\
\hline $\mathrm{C}_{20: 2}$ & 0.9 & 0.78 & 0.4 & 0.15 & 0.5 & 0.22 \\
\hline $\mathrm{C}_{20: 3}$ & $1.8^{4}$ & 0.34 & 2.1 & 1.14 & 2.7 & 0.59 \\
\hline$C_{20: 4}$ & 20.5 & 2.68 & 19.6 & 2.79 & 19.6 & 1.39 \\
\hline $\mathrm{C}_{20: 5}$ & 1.0 & 0.27 & 0.8 & 0.34 & 1.0 & 0.91 \\
\hline 8 & 0.5 & 0.29 & 0.3 & 0.23 & 0.3 & 0.31 \\
\hline $\mathrm{C}_{22: 5}$ & 1.1 & 1.03 & 1.6 & 0.80 & 0.8 & 0.90 \\
\hline $\mathrm{C}_{22: 6}$ & 5.3 & 1.39 & 5.7 & 1.63 & 6.6 & 1.09 \\
\hline $\mathrm{C}_{24: 0}$ & $3.2^{4}$ & 0.85 & $3.5^{4}$ & 0.69 & 5.5 & 1.59 \\
\hline $\mathrm{C}_{24: 1}$ & 2.9 & 1.16 & 1.54 & 0.51 & 3.4 & 0.70 \\
\hline
\end{tabular}

1 Expressed as percentage of total fatty acids by weight.

2 Ref. 16

${ }^{3}$ See text for designation of fatty acids.

- Significant at $P<0.01$ when compared with values for infants $>2,500 \mathrm{~g}$ birth weight.

- Unidentified peak.

term infants is actually diminishing from a still higher value in intrauterine life. Total erythrocyte lipid in infants under $1,200 \mathrm{~g}$ birth weight appeared to be relatively constant. There is a gradual decline in total lipid per cell through late pregnancy until term values are reached. Preliminary data suggest that this downward trend continues through early infancy to reach total lipid levels below that seen in adults, followed by a gradual rise to adult levels [18]. These variations in erythrocyte lipid content tend to parallel the changes in cell volume over these same periods of development [19]. The relative constancy of the percentage distribution of phospholipid and cholesterol in all age ranges studied suggests that much of the variation in total lipid that has been noted may be accounted for by variation in cell surface area. As previously observed, however, surface tends to increase proportionally less than volume as volume increases [11]. In infants with birth weights of less than $1,200 \mathrm{~g}$, the MCV was $39 \%$ greater than that of adult cells, while the total lipid per cell was increased $50 \%$. Comparison of infants with birth weights of less than $1,200 \mathrm{~g}$ with term infants revealed an increase of mean cell volume of $15.8 \%$ with an increase in total lipid of $17.8 \%$. Whether these discrepancies between fetal cells and adult cells may be accounted for by a thicker membrane or a more folded membrane to allow greater membrane per unit volume remains unclear. The increased incidence of pyknocytes in premature infants may be an example of extreme membrane folding accounting for some of the variability between cell lipid and cell volume [25].

The influence of nucleated red cells on the lipid content per cell was felt to be negligible. Washed cell preparations used for lipid extraction were screened by direct smear for nucleated red cells and these were consistently infrequent (less than 1/high power field). After 20 weeks of gestation, nucleated cells have been shown to account for $1 \%$ or less of the circulating erythrocytes [19]. Reticulocytes may constitute a higher percentage of the erythrocytes during this period [19]. Reticulocytes have been shown to have a larger amount of total lipid, phospholipid, and cholesterol per cell [26]. Since reticulocytes also have a larger corpuscular volume than older cells, some of the characteristics of the study group may be explained by the presence of reticulocytes. The phospholipid and phospholipid fatty acid composition of reticulocytes is similar to that of older cells, however [26]. Cord bloods containing large numbers of nucleated erythrocytes and reticulocytes (obtained from erythroblastotic infants) give values for total lipid, lipid $P$, and cholesterol significantly lower than those from infants with birth weights ranging from 200 to $1,200 \mathrm{~g}$ (total lipid = $7.11 \times 10^{-10} \mathrm{mg} /$ cell; $\mathrm{P}=1.74 \times 10^{-11} \mathrm{mg} /$ cell; cholesterol $=1.86 \times 10^{-10} \mathrm{mg} / \mathrm{cell}$ ) [17]. The phos. pholipid and phospholipid fatty acid composition of these young cell-rich cord bloods does not differ from those of normal term infants [17].

The mature erythrocyte appears incapable of de novo synthesis of membrane lipid [12]. Previous studies have emphasized that membrane lipid may be maintained either through direct exchange with plasma cholesterol and phospholipid or by acylation of plasma monoacyl phospholipid to form membrane diacyl phospholipid [3, 13, 21, 23]. Despite this dependence on the lipid environment of plasma for homeostasis, the total erythrocyte membrane lipid content appears to be relatively independent of the plasma total lipid levels [15]. The observation that total erythrocyte lipid in cord blood is higher than that found in adult blood despite circulating in a relatively hypolipemic plasma environment was further emphasized by these data in the low birth weight infant. The mean values for plasma total lipid, phospholipid, and cholesterol in the low birth weight group were all lower than mean values in term infants (total lipid: 
less than $2,100 \mathrm{~g}=243 \mathrm{mg} / 100 \mathrm{ml}$, more than 2,500 $\mathrm{g}=283 \mathrm{mg} / 100 \mathrm{ml}$; phospholipid: less than 2,100 $\mathrm{g}=90 \mathrm{mg} / 100 \mathrm{ml}$, more than $2,500 \mathrm{~g}=110 \mathrm{mg} / 100$ ml; cholesterol: less than $2,100 \mathrm{~g}=56 \mathrm{mg} / 100 \mathrm{ml}$, more than $2,500 \mathrm{~g}=68 \mathrm{mg} / 100 \mathrm{ml}$ ). Thus, a greater discrepancy between erythrocyte total lipid and plasma total lipid was evident in low birth weight infants than in normal neonates.

Many structural and functional differences between fetal and adult cells have been noted [10]. Whether any of these are directly caused by alterations in lipid composition remains unproven. One difference of major importance is in the oxygen dissociation characteristics of fetal cells which may be more closely related to the presence of a fetal membrane than fetal homoglobin [22]. Although adult cells transfused into the fetus may acquire some lipid characteristics of fetal cells [17], they retain an adult dissociation curve [4]. It would appear unlikely that this characteristic of fetal membrane is directly dependent on structural lipids which are susceptible to alteration by the plasma environment as previously postulated $[7,16]$. Evidence currently suggests that the oxygen affinity of the red cell is more directly related to the degree of binding of 2,3-diphosphoglycerate with hemoglobin [5].

\section{References and Notes}

1. Ackman, R. G.: Structural corrclation of unsaturated fatty acid esters through graphical comparison of gas-liquid chromatographic retention times on a polyester substrate. J. Amer. Oil Chem. Soc., 40: 558 (1963).

2. Bartlett, G. R.: Phosphorus assay in column chromatography. J. Biol. Chem., 234: 466 (1959).

3. Basford, J. M., Glover, J., ANd Green, C.: Exchange of cholesterol between human beta-lipoproteins and crythrocytes. Biochim. Biophys. Acta, 84: 764 (1964).

4. Battaglia, F. C., Bowes, W., McGaughey, H. R., Makowski, E. L., ANd Meschia, G.: The effect of fetal exchange transfusions with adult blood upon fetal oxygenation. Pediat. Res., 3: 60 (1969).

5. Benesch, R., BeNesch, R. E., AND Yu, C. I.: Reciprocal binding of oxygen and diphosphoglycerate by human hemoglobin. Proc. Nat. Acad. Sci. U.S.A., 59: 526 (1968).

6. Chiamori, N., and Henry, R. J.: Study of the ferric chloride method for determination of total cholesterol and cholesterol esters. Amer. J. Clin. Pathol., 31: 305 (1959).

7. Crowley, J., Ways, P., and Jones, J. W.: Human fetal erythrocyte and plasma lipids. J. Clin. Invest., 44: 989 (1965).

8. Farquhar, J. W.: Human erythrocyte phosphoglycerides. I. Quantification of plasmalogens, fatty acids and fatty aldehydes. Biochim. Biophys. Acta, 60: 80 (1962).

9. FArquhar, J. W.: Identification and gas-lipid chromatographic behavior of plasmalogen aldehydes and their acetal, alcohol and acetylated alcohol derivatives. J. Lipid Res., 3: 21 (1962).

10. Hollan, S. R., Szelenyi, J. G., Breuer, J. H., Medgyesi, G.
A., AND Sorer, V. N.: Structural and functional differences between human foctal and adult erythrocytes. Haematologica, 4: 409 (1967).

11. Houchin, D. N., Munn, J. I., And Parnell, B. L.: A method for the measurement of red cell dimensions and calculation of mean corpuscular volume and surface area. Blood, 13: 1185 (1958).

12. Marks, P. A., Gelluorn, A., ANd Kidson, C.: Lipid synthesis in human leukocytes, platelets, and erythrocytes. J. Biol. Chem., 235: 2579 (1960).

13. Mulder, E., ANd VAN Deenen, L. L. M.: Metabolism of red cell lipids. I. Incorporation in vitro of fatty acids into phospholipids from mature erythrocytes. Biochim. Biophys. Acta, 106: 106 (1965).

14. Neerhout, R. C.: Abnormalities of erythrocyte lipids in hepatic disease. J. Lab. Clin. Med., 71: 438 (1968).

15. Neerhour, R. G.: Erythrocyte stromal lipids in hyperlipemic states. J. Lab. Clin. Med., 71: 448 (1968).

16. NeERhout, R. C.: Erythrocyte lipids in the neonate. Pediat. Res., 2: 172 (1968).

17. NeERhout, R. C.: Alteration of adult erythrocyte lipids during fetal circulation. Western Soc. Pediat. Res., Denver, Colo., November 1968.

18. NeERIIOUT, R. C.: Unpublished observation.

19. Oski, F. A., ANd Naiman, J. L.: Hematologic Problems in the Newborn, p. 4 (Saunders, Philadelphia, 1966).

20. Parker, F., ANd Peterson, N. F.: Quantitative analysis of phospholipids and phospholipid fatty acids from silica gel thin-layer chromatography. J. Lipid Res., 6: 455 (1965).

21. Sakagami, T., Minari, O., AND ORII, T.: Interaction of individual phospholipid between rat plasma and erythrocytes. Biochim. Biophys. Acta, 98: 356 (1965).

22. Schruefer, J. J. P., Heller, C. J., Battaglia, F. C., ANd Hellegers, A. E.: Independence of whole blood and haemoglobin solution oxygen dissociation curves from haemoglobin type. Nature, 196: 550 (1962).

23. Shohet, S. B., Nathan, D. G., and Karnovsky, M. L.: Stages in the incorporation of fatty acids into red blood cells. J. Clin. Invest., 47: 1096 (1968).

24. Skipski, V. P., Peterson, R. F., and Barclay, M.: Separation of phosphatidylethanolamine, phosphatidylserine and other phospholipids by thin layer chromatography. J. Lipid Res. 3: 467 (1962).

25. Tuffy, P., Brown, A., And Zuelzer, W. W.: Infantile pyknocytosis. A common erythrocyte abnormality of the first trimester. Amer. J. Dis. Child., 98: 227 (1959).

26. Van Gastel, C., Van den Berg, D., de Gier, J., and VaN DEENEN, L. L. M.: Some lipid characteristics of normal red blood cells of different age. Brit. J. Haematol., 11: 193 (1965).

27. IVAys, P., ANd Hanahan, D. J.: Characterization and quantification of red cell lipids in normal man. J. Lipid Res., 5: 318 (1964).

28. Ways, P., Reed, C. F., and Hanahan, D. J.: Red cell and plasma lipids in acanthocytosis. J. Clin. Invest., 42: 1248 (1963).

29. ZEE, P.: Lipid metabolism in the newborn. I. Phospholipids in cord and maternal sera. Pediatrics, 39: 82 (1967).

30. ZEE, P.: Lipid metabolism in the newborn. II. Neutral lipids. Pediatrics, 41: 640 (1968).

31. Informed consent was obtained for all subjects in this study. 32. Model B, Coulter Electronics, Hialeah, Fla. 
33. Silica Gel H, Brinkman Instruments, Inc., Westbury, N.Y.

34. Model 810, Perkin-Elmer Corporation, Norwalk, Conn.

35. Perkin-Elmer Corporation.

36. Applied Science Laboratories, Inc., State College, Pa.

37. Supported by Public Health Service Research Grant no. 5RO1-HD02124, and the Robert Shaw Memorial Fund.
38. Request for reprints should be addressed to: R. C. Neerhout, M.D., Division of Hematology, Department of Pediatrics and The Gwynne Hazen Cherry Memorial Laboratory, University of California School of Medicine, Los Angeles, Calif. 90024 (USA).

39. Accepted for publication January 9, 1970. 